\title{
Cellular Kinetics of Gastrointestinal Mucosa, with Special Reference to Gut Endocrine Cells
}

\author{
Hideto InOKuchi, Sotaro Fujimoto and Keiichi KawAI \\ Department of Preventive Medicine (Prof. K. KAw AI), Kyoto Prefectural University of Medicine, Kyoto, \\ Japan
}

Received January 5, 1983

Summary. After ${ }^{3}$ H-thymidine autoradiography was introduced to the study of cellular kinetics, the epithelial cells of the gastrointestinal mucosa have been examined extensively with regard to their kinetic behavior. After reviewing the knowledge on the kinetics of different epithelial cells in the stomach and small and large intestine, this article concentrates on the origin, differentiation and turnover of gut endocrine cells which have been under much controversy.

Autoradiographic and other investigations of EC cells support the view that these cells are not neuroectodermal in origin, but differentiate from an immature type of gut epithelial cells. We investigated the kinetics of the antral $G$ cells in the hamster, $G$ cells and $S$ cells in the rat duodenum by the combined utilization of ${ }^{3} \mathrm{H}$-thymidine autoradiography with immunohistochemistry, and confirmed that these cells are derived from the same precursor cells as the other mucosal cells of the gastrointestinal tract. The half-life of the antral $G$ cells was estimated at 10-15 days, while the turnover time of the $G$ cells and $S$ cells in the duodenum were calculated at 3-4 days and 2 days, respectively. These data also support the belief that gut endocrine cells originate from the endoderm.

Histopathological alterations such as antral gastritis and intestinal metaplasia, as well as vagal denervation, were shown to influence the population of the antral G cells in man and the hamster. This supports the view that intrinsic and extrinsic stimuli might alter the kinetics of gut endocrine cells.

Study of cell renewal of the gut mucosa has a long history. Before the second half of the nineteen-fifties, however, most investigations were qualitative or remained at the level of a hypothesis. No dynamic experimental means of revealing the kinetic aspect of a cell had yet been found.

In 1958 , autoradiography by ${ }^{3} \mathrm{H}$-thymidine was introduced to the study of cellular kinetics, and caused rapid progress in research in the field of the gastrointestinal tract. Thymidine is a component of DNA, and, when given to experimental animals, thymidine labelled with ${ }^{3} \mathrm{H}$ is taken specifically into cells synthesizing DNA. As $\beta$-ray from ${ }^{3} \mathrm{H}$ in the nucleus is detectable with photosensitive emulsion, the cells with mitotic activity are able to be identified. ${ }^{3} \mathrm{H}$-thymidine, once taken into a cell, remains as a stable DNA component as long as the nuclear DNA is not resolved and the daughter cells can also be identified as labelled cells, though ${ }^{3} \mathrm{H}$-thymidine is diluted by cell divisions. Application of ${ }^{3} \mathrm{H}$-thymidine autoradiography made it possible to pursue various kinds of cells of gut mucosa as labelled cells. To date, a great deal of detailed 
data and new knowledge concerned with surface epithelium and various kinds of glandular cells in almost all sections of the gastrointestinal tract have been accumulated. In contrast, the kinetics of gut endocrine cells had not been studied until recently.

The cells today known as gut endocrine elements have been recognized as "basalgranulated cells" scattered throughout the gastrointestinal mucosa since the early days of Heidenhein (1870) and Kultschitzky (1897). Recent striking progress in ultrastructural study and immunocytochemistry made the specific identification of gut endocrine cells possible among them. At present, more than fifteen different gut endocrine cells have been identified and classified ultrastructually. Nevertheless, to the present, the main interest of most studies on gut endocrine cells has lain in areas such as their ultrastructure, their distribution in normal or pathological states, and the physiology or pathophysiology of gut hormones contained in the cells.

These cells had been traditionally considered to be a static cell group with no division and no renewal (Patzelt, 1936). Pearse (1966, 1968, 1969), on the other hand, found a common property between the gut endocrine cells and other endocrine cells, i.e., the ability of their amine-precursor-uptake and decarboxylation (APUD), and postulated that gut endocrine cells are derived from the neural crest (PEARSE, 1969; PEARSE and PoLAK, 1971). The cells with APUD activity are widely distributed in the pineal body, hypophysis, pancreas, thyroid gland and carotid body. Pearse (1977) categorized these cells including basal-granulated cells in the gut as the APUD series. This concept was broadly supported not only because of its proposal of a comprehensive interpretation of the endocrine cells in a whole body and its new position to the basal-granulated cells, but also from its original viewpoint on histogenesis. Nevertheless, there is much controversy over the actual origin of the gut endocrine cells (CHENG and LEBLOND, 1974c; ANDREW et al., 1982). In such a historical context, investigating the detailed kinetics of each type of the gut endocrine cells is also expected to cast more light on its enigmatic origin.

In this paper, the cellular kinetics of gut endocrine cells which have interested the authors for a few years will be mainly reviewed. The kinetics of these cells, however, should not be discussed separately from that of other mucosal cells. Accordingly, discussion on the data by ${ }^{3} \mathrm{H}$-thymidine autoradiography of the surface epithelium and various exocrine cells in each part of the gastrointestinal tract will be included.

\section{CELLULAR KINETICS OF GASTROINTESTINAL MUCOSA}

\section{The stomach}

Human gastric mucosa consists of the cardiac, fundic and pyloric gland area. Both the cardiac and pyloric glands are simple mucus-secreting structures with indistinguishable similarities in morphological and chemical nature. The mucosal surface is lined with a layer of columnar surface epithelium. The fundic gland is basically a simple tubular gland, and consists of generative cells (proliferative cells) localized from the bottom of the gastric pit to the isthmus and four kinds of cells localized below the isthmus, i.e., parietal cells (oxyntic cell), chief cells (zy mogenic cell), mucous neck cells (immature chief cell) and endocrine cells. On the other hand, the pyloric gland is a simple alveolar gland with branching, and consists of three kinds of cells, i.e., generative cells, mucoid cells and endocrine cells.

In this chapter, the cellular kinetics of the gastric mucosal cells except endocrine cells (described later) will be discussed. 


\section{The surface epithelium}

Mitotic figures are frequently encountered in the epithelial cells immediately above the isthmus of the fundic glands. Bizzozero $(1888,1893)$ found transitional forms to each cell on the way from the bottom of the gastric pit to the mucosal surface, and concluded that the surface epithelium is renewed actively by the epithelial cells at this generative cell zone.

After ${ }^{3} \mathrm{H}$-thymidine autoradiography was introduced to the study of cellular kinetics in 1958, Quastler and Sherman (1959), Leblond and Messier (1958), Messier and Leblond (1960), Hunt and Hunt (1962), Lipkin et al. (1963) and KAKu et al. (1962) successively reported on the cellular kinetics of the stomach or intestine. By this series

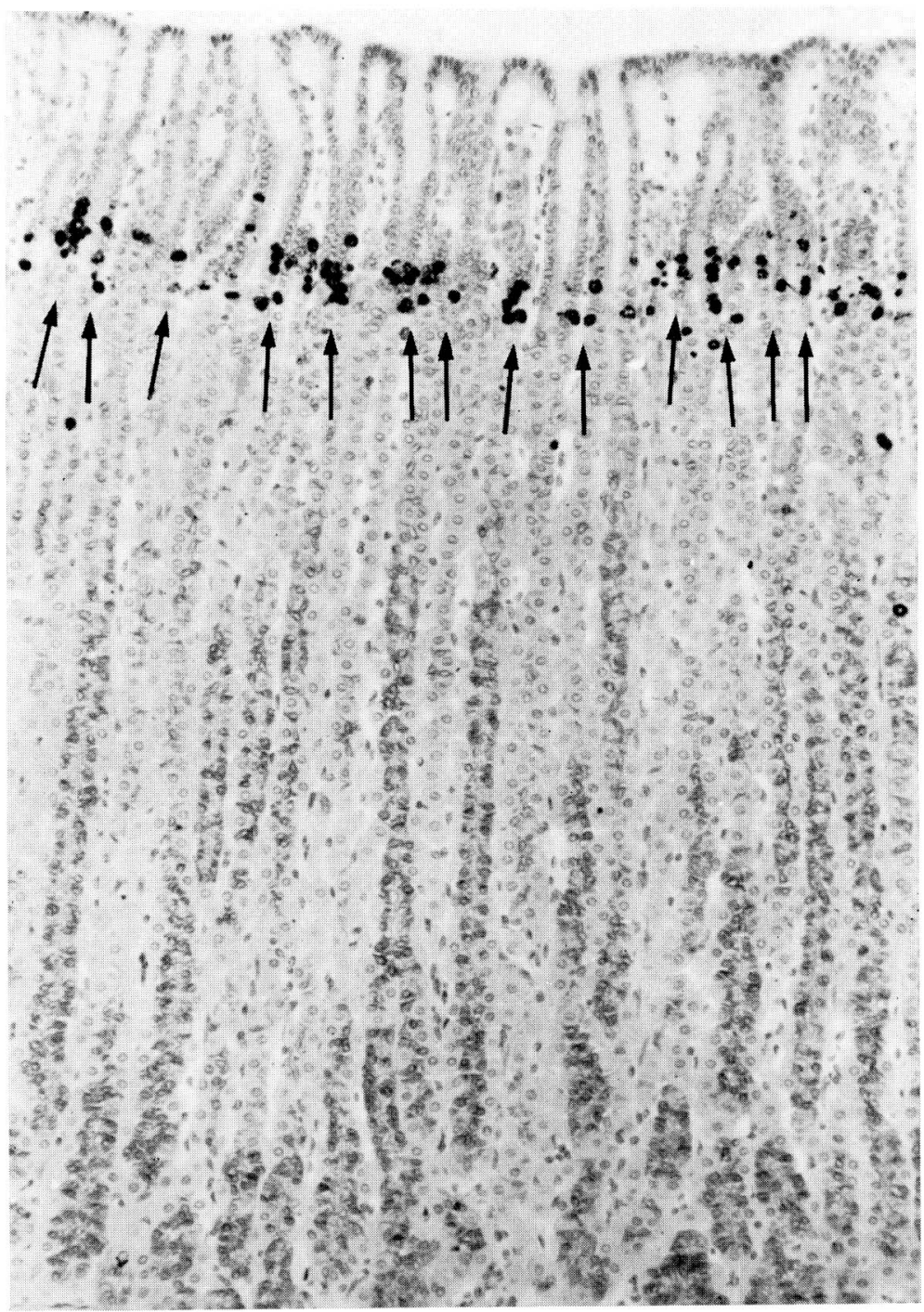

Fig. 1. Autoradiograph of the fundic mucosa of the hamster by flash labelling of ${ }^{3} \mathrm{H}$-thymidine. Arrows indicate labelled cells. 
of studies, the distribution of generative cells in the gastric mucosa was clearly shown and the kinetics of the surface epithelium was clarified. As ${ }^{3} \mathrm{H}$-thymidine is taken specifically into the cells synthesizing DNA, the number and location of the proliferating cells can be clearly identified by autoradiography after a single administration of ${ }^{3} \mathrm{H}$-thymidine (flash labelling method, Fig. 1). Further, application of ${ }^{3} \mathrm{H}$-thymidine autoradiography enabled the investigation of the kinetic parameters, i.e., DNA synthesizing time and cell cycle time, and the cell migration patterns.

Messier and Leblond (1960) traced labelled cells at regular intervals after ${ }^{3} \mathrm{H}-$ thymidine administration (pulse labelling method), and confirmed that most of the cells produced at the generative cell zone migrated to the mucosal surface and were transformed into surface epithelium. The life span of the surface epithelium, from the reports of many investigators (Messier and Leblond, 1960; Hunt and Hunt, 1962; Hattori, 1975; Hattori and Fujita, 1976a), amounts to $3-4$ days in the fundic, pyloric and cardiac glands, with little species difference.

On the other hand, KAKU (1966) and HatToRI and Fujita (1976b) estimated the cell cycle time and DNA synthesizing time of a generative cell in the rat and hamster at approximately $30 \mathrm{hrs}$ and $7 \mathrm{hrs}$, respectively. LiPKIN et al. (1963) reported the cell cycle time and DNA synthesizing time in generative cells of the human stomach as about 40 and $10 \mathrm{hrs}$, respectively. Thus, the generative cells at the isthmus repeat mitosis at $30 \mathrm{hr}$ intervals in the hamster and rat, and $40 \mathrm{hr}$ intervals in humans. These continuous cell divisions lead the immature surface epithelium after the final mitosis, to migrate towards the mucosal surface, while the intracellular organelles develop and secreting granules begin to form (HATTORI and FuJITA, 1976a). The cell migration from the gastric pit to mucosal surface is successive, just like the movement of an escalator.

\section{The fundic gland}

The kinetics of the glandular cells is considerably different from that of the surface epithelium. Before the latter half of the 1960's no kinetic analysis of the fundic gland had been reported. Although the surface epithelium is renewed at relatively short intervals, the cell migration to the lower part of the glandular portion is extremely slow and complex.

Willems et al. (1972) proposed that chief cells are renewed by self-replication, judging from the observation that there were always DNA synthesizing cells, scanty as they were, among the chief cells and mucous neck cells. Contrary to this, from the investigation using the cumulative and pulse labelling method of ${ }^{3} \mathrm{H}$-thymidine, HatToRI (1974) and HatToRI and FujiT A (1976a) insisted on a cell supply to the chief cell coming from the generative cell zone at the isthmus. They suggested that, although a few chief cells have the ability for self-replication, most of them are differentiated from the mucous neck cells in about 50 days. Furthermore, simulating a stochastic migration model, they estimated the life span of both parietal and chief cells at around 200 days. Thus, when mucous neck cells are regarded as immature and intermediate cells as chief cells, this model well explains the characteristic distribution pattern of mucous neck cells located at the upper part of the fundic gland and chief cells at the lower part. They also inferred that the difference in the distribution between parietal cells and chief cells is based on the difference in their migration speed downwards from the generative cell zone. This migration pattern, different from the pipe line system of the intestinal epithelium (first produced, first lost), is attended with the phenomenon of "passing and being passed" cell migration, and has been named the "stochastic flow system." 


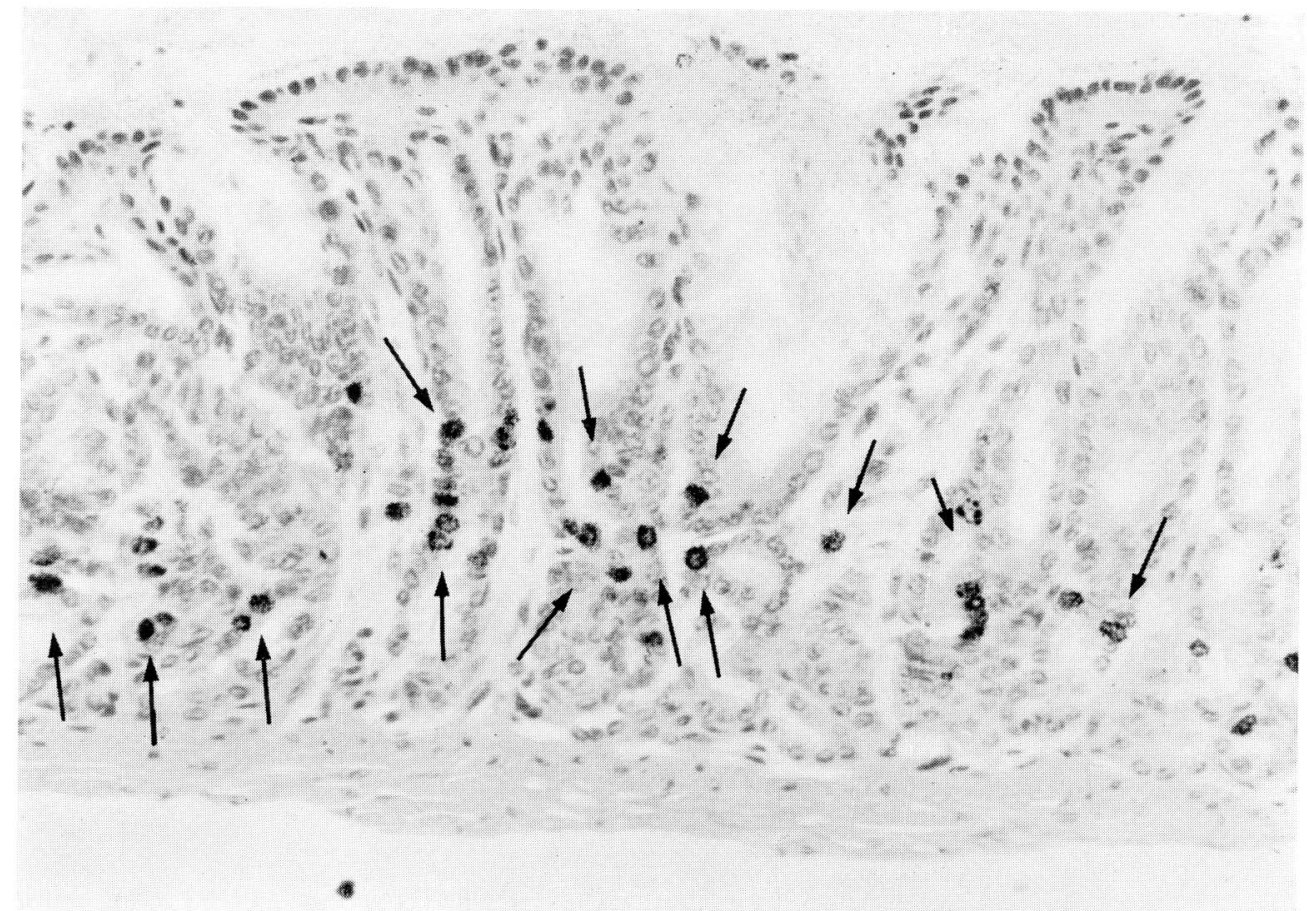

Fig. 2. Autoradiograph of the pyloric mucosa of the hamster by flash labelling of ${ }^{3} \mathrm{H}$-thymidine. Arrows indicate labelled cells.

\section{The pyloric gland}

The main component cell of the pyloric gland is a large mucus-secreting cell. Kinetic studies of the pyloric gland have been extremely scarce. One of the reasons for this is that the pyloric gland was long regarded as a simple mucous gland and received less attention. Nowadays, however, it has been shown that the pyloric gland contains several kinds of gut endocrine cells and plays as important a role as the fundic gland in the gastric function.

HatToRi and Fujita (1976b) labelled the pyloric gland cells of a hamster with ${ }^{3} \mathrm{H}$ thymidine by a cumulative and pulse labelling method, and investigated the process by which the labelled cells were lost. They reported that the renewal of the pyloric gland cells of the hamster had a life span of around 14 days via the pipe line system. Concurrently they inferred, from an analysis of the decreasing pattern of the labelling index, that there must be another cell group different in cell kinetics from the pyloric gland cells with the life span of 14 days. This cell group has been clarified by the identification of the endocrine cells and the recent analysis of their kinetics.

\section{The small intestine}

As previously stated, it has been known since Bizzozero $(1888,1893)$ that the epithelium of the gastrointestinal mucosa is in the process of constant renewal. Figure 3 shows a ${ }^{3} \mathrm{H}$-thymidine autoradiograph of a rat intestinal crypt after a single injection. The labelled cells, as seen in Figure 3, are distributed mainly in the lower part of the crypt, and it is clear that only at this portion (generative cell zone) are the cells constantly 


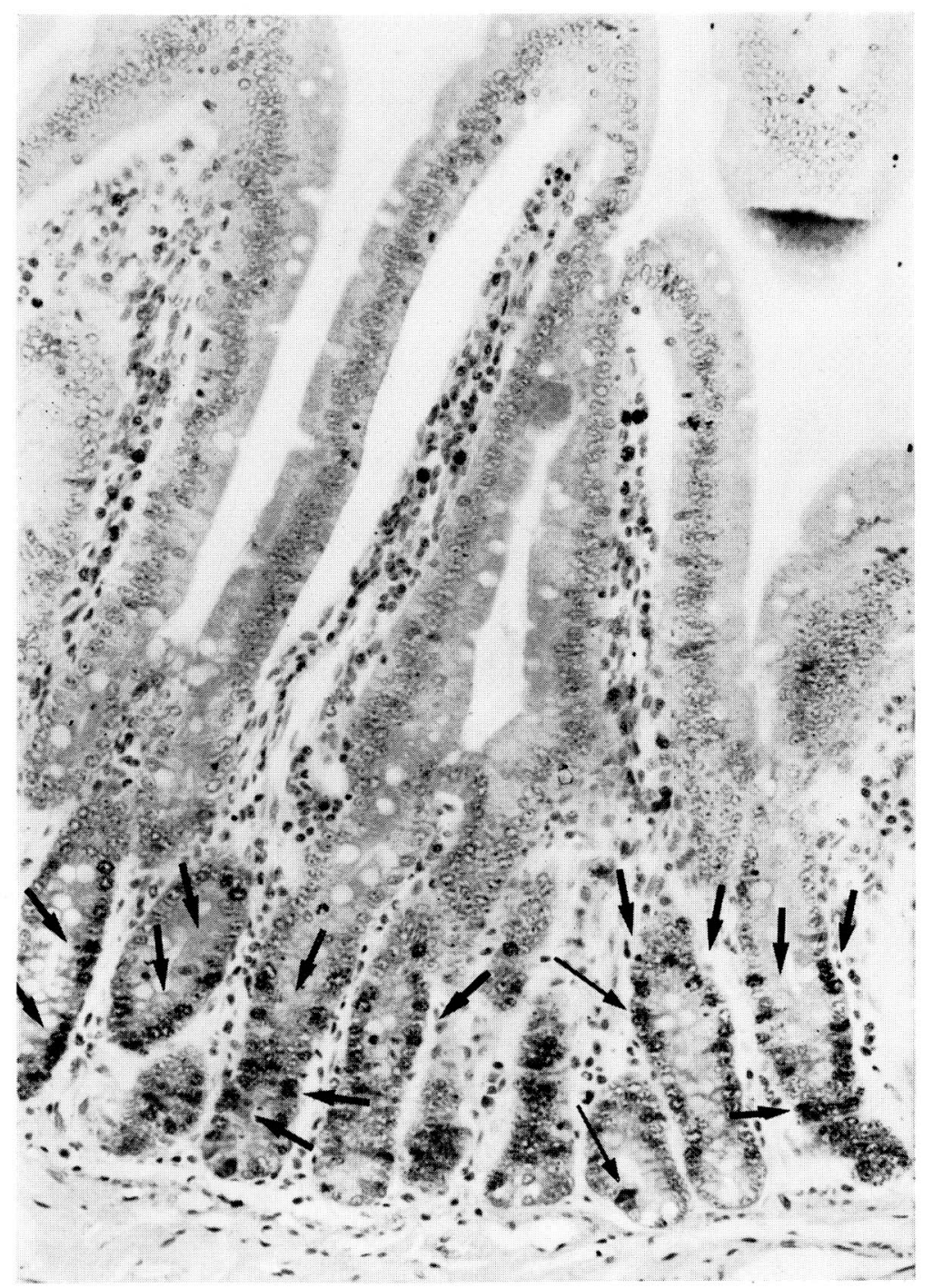

Fig. 3. Autoradiograph of the upper jejunum of the rat by flash labelling of ${ }^{3} \mathrm{H}$-thymidine. Arrows indicate labelled cells.

renewed. All the component cells, e.g., columnar cells, goblet cells or Paneth cells, are supplied from this zone.

The frequency of mitosis in the generative cell zone is particularly higher at the bottom of crypts. The labelling indices caluculated in sections sliced parallel to the surface from the bottom of a crypt result as shown in Figure 4. The low labelling indices at the cell location numbers 10 to 30 are due to the intermixture of villus cells without mitotic activity, and relatively low labelling indices at the bottom may be due to mixed pre-Paneth cells.

The cell cycle time of a generative cell in the small intestine has been, so far, found to be around $14 \mathrm{hrs}$ in the mouse or rat (Quastler and Sherman, 1959; Kaku, 1962; Cairnie et al., 1965; Hagemann et al., 1970; Schultze et al., 1972; Kovacs and Potten, 


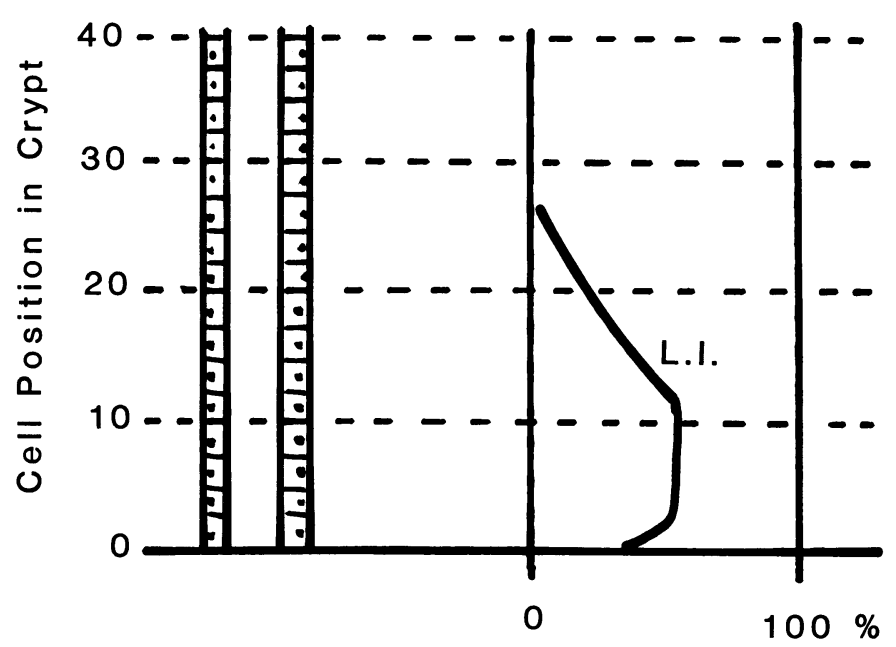

Fig. 4. Correlation between labelling index (LI) and cell position in the crypt. (Reproduced by permission from S. Fujita, Nihon Ishikai Zasshi 67, 1972).

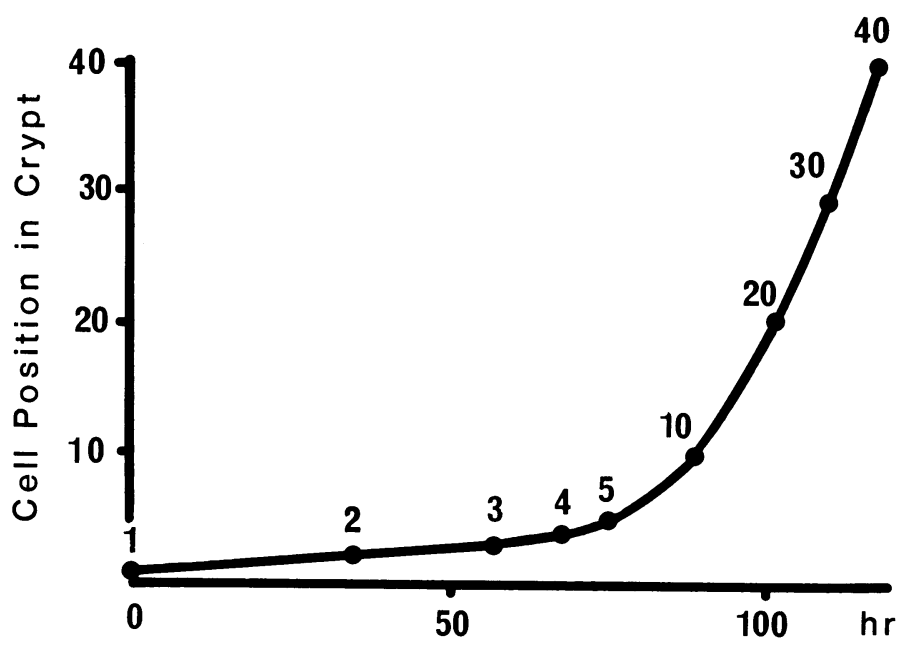

Fig. 5. Velocity of cell migration in the crypt. (Reproduced by permission from S. FuJita, Nihon Ishikai Zasshi 67, 1972).

1973), from which the migration speed of a cell at a certain site in a crypt can be inferred as in Figure 5. As shown in Figure 5, the deeper a cell is located in a crypt, the slower it moves. For instance, it takes $120 \mathrm{hrs}$ for a cell at the base of a crypt to reach its opening, while a cell at the location number 20 can emerge from the crypt in around 15 hrs. Such migration in the crypt is basically an upwards perpendicular progression, but a movement in a right-angled direction, shifting horizontally in a crypt, may occur in a few cases.

Under normal conditions, both villus cells and generative cells are constant in number, and preserve the dynamic equilibrium. In addition, the generative cell zone is always located at the lower part of a crypt. This dynamic equilibrium and peculiar distribution can not be explained from the ambivalent mitosis of generative cells. 


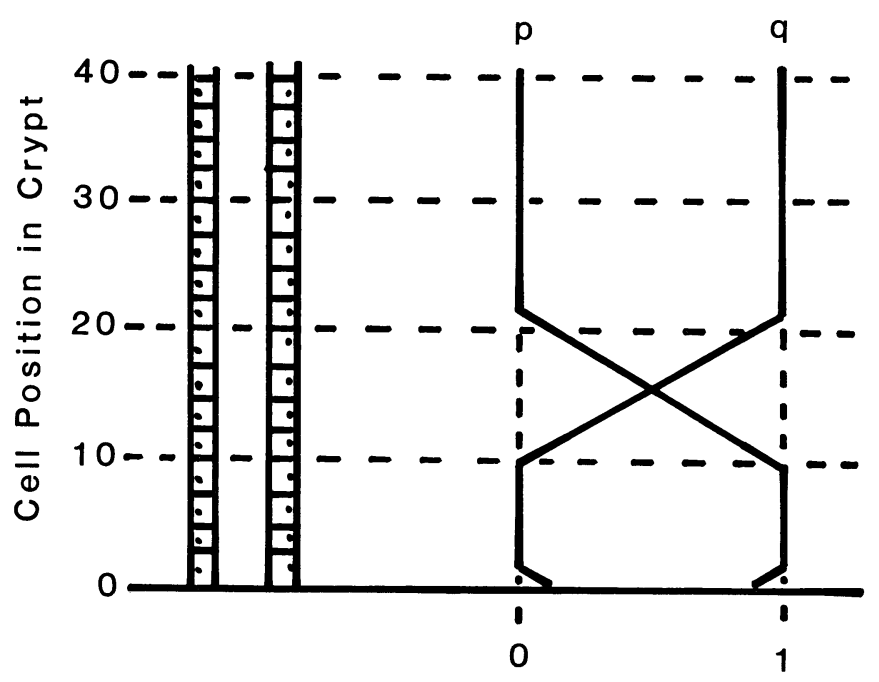

Fig. 6. Diagram of the p, q model. (Reproduced by permission from S. Fujita, Nihon Ishikai Zasshi 67, 1972). p: probability to remain as a generative cell. $\mathrm{q}$ : probability to differentiate to a villus cell.

Figure 6 is a model explaining the difference in distribution beween generative cells and villus cells, that is, according to the location of the generative cells, the probabilities whether a daughter cell remains as a generative cell or differentiates to a villus cell are fixed. The point of intersection of these two probabilities $\mathrm{p}$ and $\mathrm{q}$ is called the "critical zone of differentiation."

\section{The columnar cell}

In the small intestine the mucosa contains columnar cells, goblet cells, Paneth cells and endocrine cells, and yet the columnar cells form a large majority and play a decisive role in cell renewal. The columnar cells produced in the crypts overflow out of the opening of the crypts and migrate smoothly to the villus tips (LEBLOND and STEvens, 1948; Leblond and Messier, 1958; Quastler and Sherman, 1959; Messier and Leblond, 1960; KAKU, 1962; CAIRnie et al., 1965; Cheng and LeBlond, 1974a). This migration can be considered an escalator-like movement by its way of sliding on the basement membrane. Furthermore, by tracing the labelled cells with ${ }^{3} \mathrm{H}$-thymidine, it can be seen that newly labelled villus cells climb up the villi and push up the non-labelled villus cells. The border between labelled and non-labelled cells in this process is apparently clear, and there seems to be neither passing nor being passed procedures among the villi. This process called the "turn over by pipe line system" and the motive power of this type of cell migration is thought to be based on cell proliferation in the crypts. In the process of the cell's migration to the villus tips, the cells move temporally in a slow stream with a big horizontal vector at the transitional zone, and it is believed that several crypts can supply cells to one villus. This may mean that, in the transitional zone, cells from the right and left sides are mixed with each other. Once reaching a villus, a cell goes up by the pipe line system and falls into the intestinal lumen from the extrusion zone on the villus tip (BERTALANFFY and NAGI, 1961).

According to reports up to the present, the time transpiring for the replacement of 
the villus cells is $1-2$ days, and the turnover time of columnar cells is estimated at 3-4 days.

\section{The goblet cell}

Goblet cells are ordinarily found in the intestinal mucosa. Although a few goblet cells are capable of mitosis (CAIRnie, 1970; Shimamoto, 1970), a majority is produced from generative cells in crypts. Labelled goblet cells appear in the villus 20-24 hrs later than labelled columnar cells after ${ }^{3} \mathrm{H}$-thymidine administration (MERzEL and LEBLOND, 1969; CAIRNIE, 1970). Both cells, however, migrate along the villi at the same speed. This suggests that the differentiation of goblet cells occurs at a deeper position in the crypts, corresponding to the above-mentioned time of $20 \mathrm{hrs}$, than that of columnar cells (Cheng and Leblond, 1974a; ChenG, 1974a). Specifically, the cells determined to differentiate to goblet cells stay as pre-goblet cells for a while, and then appear in the villi as mature goblet cells.

\section{The Paneth cell}

Paneth cells are usually located at the bottom of the crypts and, unlike the other cell types, do not show any upward migration. To date, it has been shown that the Paneth cell has no self-replicating ability (Throughton and Trier, 1969; Cheng et al., 1969, CAirnie, 1970; Cheng, 1974b), and seems to be derived from crypt-base columnar cells and degenerate in situ (Cheng at al., 1969; Cheng, 1974b). The turnover time of the population is thought to be much longer than that of goblet cells (CHENG et al., 1969; CAirnie, 1970; Cheng, 1974 a, b).

\section{Brunner's gland}

NiKI et al. (1980) reported the kinetic behavior of Brunner's gland from an analysis of ${ }^{3} \mathrm{H}$-thymidine autoradiography stating that, basically, the cells of Brunner's gland are not supplied from the generative cell zone in the crypts but produced in situ corresponding to the cell loss by the proliferation of mature glandular cells at need and at random. They estimated a half life time of approximately 40 days.

\section{The large intestine}

The mucosa of the large intestine consists of columnar cells, goblet cells and endocrine cells, and are also renewed very rapidily. The generative cells are located in the lower half of a crypt (Fig. 7). The cell cycle time of the generative cells measured by the fraction mitosis curve has been estimated at $23 \mathrm{hrs}$ in the mouse (CHANG and NADLER, 1975) and human (LIPKIN et al., 1963). In addition SUNTER et al. (1979) reported a varied cell cycle time according to different sites of the rat colon, namely, $25 \mathrm{hrs}$ in the cecum, $35 \mathrm{hrs}$ in the ascending colon, $42 \mathrm{hrs}$ in the transverse colon and $58 \mathrm{hrs}$ in the descending colon.

The fashion of cell renewal in the large intestine is more or less similar to that in the small intestine but the renewal rate or turnover time of each component cell is quite longer than in the small intestine. CHANG and LeBlond (1971) identified three types of cell lines in the mouse large intestine, i.e., vacuolated-columnar, mucus (goblet) and argentaffin cell lines. In the series of their studies (ChANG and Leblond, 1971; Chang and Nadler, 1975; Tsubouchi and Leblond, 1979), it was described that vacuolated-columnar cells and mucus cells were found to be capable of mitosis in the mid or lower crypts, to migrate upwards and be lost from the mucosal surface within a life span of about 4.6 days. 


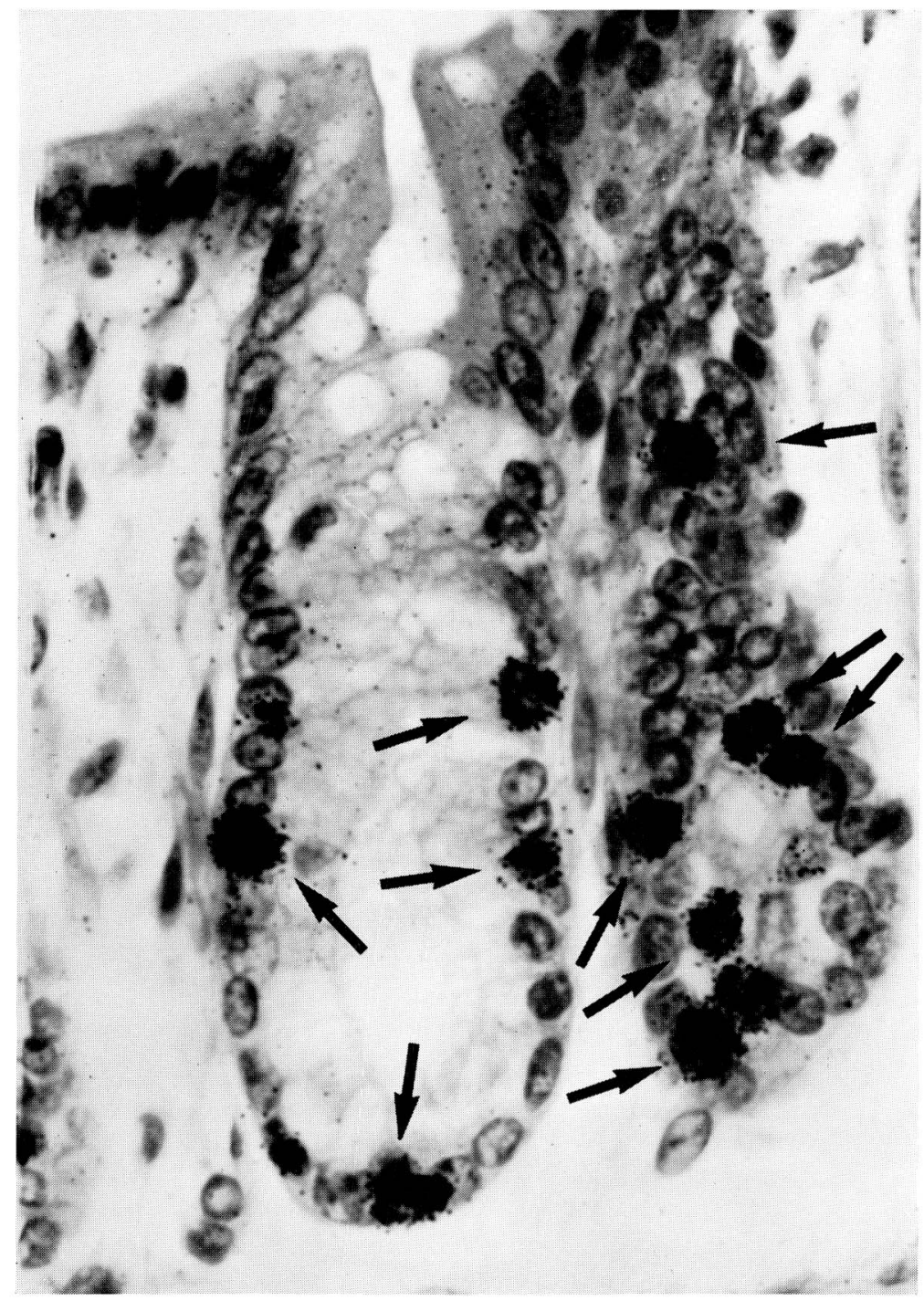

Fig. 7. Autoradiograph of the colonic mucosa of the hamster by flash labelling of ${ }^{3} \mathrm{H}$-thymidine. Arrows indicate labelled cells.

\section{CELLULAR KINETICS OF GUT ENDOCRINE CELLS}

\section{The enterochromaffin cell (EC cell)}

The kinetics of the EC cell has been investigated mostly in gut endocrine cells, because the combined use of ${ }^{3} \mathrm{H}$-thy midine autoradiography with more conventional techniques such as diazo-reaction was not difficult, whereas the specific identification of other gut endocrine cells was nearly impossible until the introduction of immunohistochemistry.

So far, only one report by HATTORI et al. (1977) on the kinetics of EC cells in pyloric gland is available. They found no labelled diazo positive EC cells in the pyloric gland of the hamster after flash labelling of ${ }^{3} \mathrm{H}$-thymidine, and observed that cumulative 
labelling for 10 and 20 days caused EC cells to be labelled at $31 \%$ and $63 \%$ respectively; labelled EC cells initially appeared at the isthmus near the generative cell zone and then with time in the lower part of the glands after the cessation of ${ }^{3} \mathrm{H}$-thymidine administration. They subsequently postulated that EC cells in the pyloric glands of the hamster are produced from precursor cells at the isthmus (=generative cell) and then migrate downwards. As the regression pattern in the labelling index showed an exponential decreasing curve with time, they inferred that the cell loss conformed to the "random loss system," and estimated the half life of the EC cell population at around 15 days on the average.

The kinetics of EC cells in the small intestine has been studied in the mouse and hamster (Odartchenko et al., 1970; Ferreira and Leblond, 1971; Chang and Leblond, 1974; NiKI. 1980). These investigators employed diazo-reaction or electron microscopy for the identification of the cells, in combination with ${ }^{3} \mathrm{H}$-thymidine autoradiography. On the basis of the first report by Deschner and LiPKin (1966) by the combination of diazo-reaction with ${ }^{3} \mathrm{H}$-thymidine autoradiography, OdARTCHENKo et al. (1970) investigated EC cells in the mouse duodenum using the same procedures. Recognizing the labelling in diazo-positive cells in the duodenal crypts, the frequency of the labelling being high in the medium and weak diazo-positive cells, they concluded that the proliferation of EC cells in the duodenum occurs mainly in less differentiated cells and possibly in a group of precursors that are hardly recognizable as belonging to the EC cell series. At the same time, they concluded the replacement time of EC cells in villi to be $72 \mathrm{hrs}$, due to the fact that EC cells were labelled in $33 \%$ in $24 \mathrm{hrs}$ by ${ }^{3} \mathrm{H}-$ thymidine multi-injections, and that the migration speed of EC cells is slower than that of other epithelial cells. In succession, FERREIRA and Leblond (1971), and ChenG and LEBLOND (1974b) gave a full picture of the kinetics by making a detailed and comprehensive study of "entero-endocrine cells" in the mouse small intestine, using iron hematoxylin staining and electron microscopy together with ${ }^{3} \mathrm{H}$-thymidine autoradiography. In a series of reports they described that a self-proliferative ability was not seen in entero-endocrine cells including EC cells but only in a small number of premature "young entero-endocrine cells" at the crypt-base. By analyzing the ${ }^{3} \mathrm{H}-$ thymidine autoradiography, they concluded that EC cells in the small intestine are derived from immature precursor cells at the crypt-base, lose their proliferative ability with the advance of maturation and move towards the villus tip to fall into the intestinal lumen. The maturation time and turnover time were estimated as about 2 and 4 days respectively. From these results, the observation by OdARTchenko et al. (1970) that labelled EC cells appeared later than other labelled epithelial cells suggests that the differentiation to EC cells occurs at a deeper position than the other epithelial cells. Incidentally, whether or not the EC cell is judged proliferative by light microscopy depends on not only its stage of maturation but the sensitivity of the staining method for EC cells as well. We have reported on an immunohistochemical demonstration of EC cells using anti-serotonin serum (INOKUCHI et al., 1982) and recently found that this method is much more sensitive in selectively detecting the EC cells than conventional techniques such as diazo-reaction (unpublished data). Actually, some EC cells could be shown to have mitotic activities via immunohistochemical demonstration.

The kinetics of EC cells in the large intestine was reported earliest of all the endocrine cells in the gastrointestinal tract (DESCHNER and LIPKIN, 1966). Its details were, however, not clearly explained until recently. Observing mitosis and labelling after the administration of ${ }^{3} \mathrm{H}$-thymidine among diazo-positive cells, Deschner et al. (1966) reported the proliferative activity of EC cells in the human rectum, and estimated the 
replacement time of the EC cell population as 35-100 days from the rate of increase in the labelled cells. On the other hand, ChANG and LeBLond (1971) and Tsubouchi and LEBLOND (1979) investigated EC cells in the descending colon of the mouse and found no proliferative activity in those cells. Analyzing autoradiography by continuous infusion of ${ }^{3} \mathrm{H}$-thymidine in their consecutive studies, they concluded that EC cells are derived from immature precursor cells, migrate more slowly than other cell lines and are probably lost from the mucosal surface. They estimated the turnover time of EC cells in the mouse colon as 23.3 days.

By the kinetic studies, the EC cell population has been proven not to be static but to be constantly renewed. It has also been shown that EC cells are produced from the immature precursor cells and their kinetic behaviors are quite different among the pyloric gland, small intestine and large intestine. Such differences in their migration pattern and life span in the different sites of the gut is thought to be based on the sitespecific mucosal architecture and the difference in the cell cycle time among them.

\section{The gastrin cell (G cell)}

McGuigan (1968) first identified G cells by an immunofluorescence method for gastrin. G cells are distributed mainly in the pyloric gland but they are also found in the duodenal mucosa in a considerable number.

LEHY and WILLEMS (1975), combining ${ }^{3} \mathrm{H}$-thymidine autoradiography with an immunohistochemical demonstration of gastrin, observed a number of mitotic figures in mouse antral $\mathrm{G}$ cells after colchicine administration; labelled gastrin cells comprised $0.45-0.48 \%$ by a single injection of ${ }^{3} \mathrm{H}$-thymidine. Consequently they concluded that the $\mathrm{G}$ cell population is not static but continuously renewed. Furthermore, by analyzing autoradiographs after a single and a series of six injections of ${ }^{3} \mathrm{H}$-thy midine (LEHY

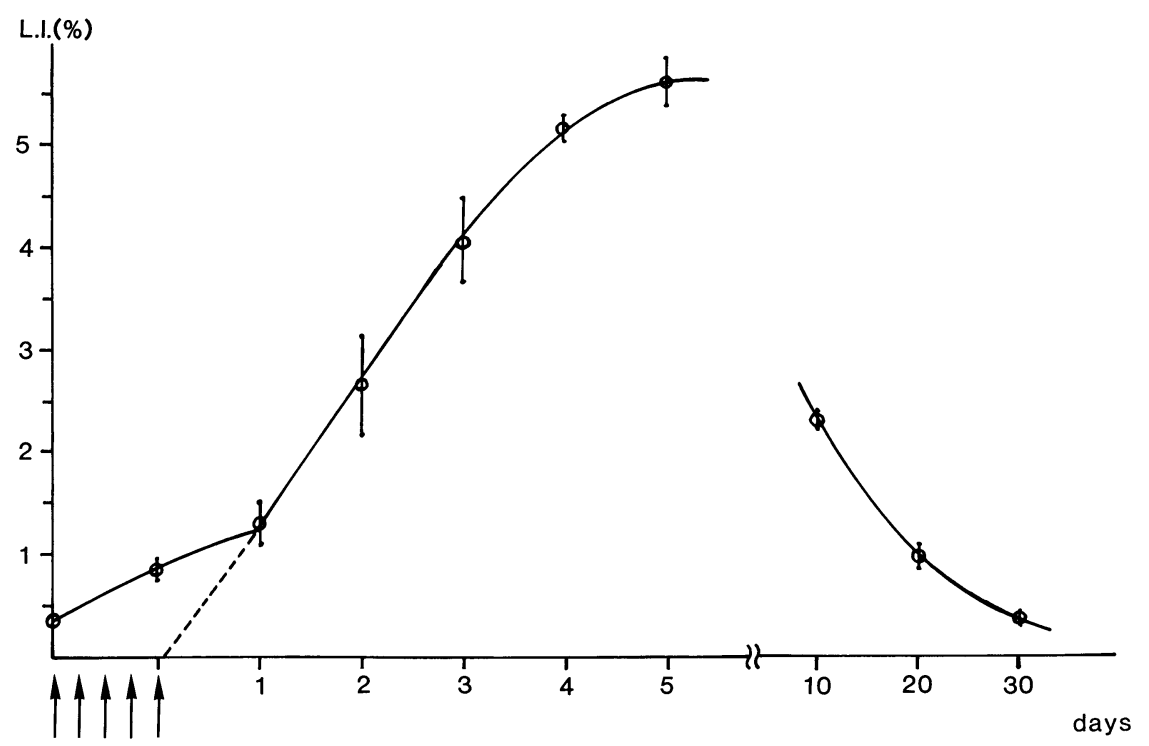

5 repeated injections of $3 \mathrm{H}-\mathrm{TdR}$

Fig. 8. Labelling index of $\mathrm{G}$ cells during and after a series of 5 injections of ${ }^{3} \mathrm{H}$-thymidine. (Reprinted by permission of the publisher from the article by S. Fujimoto et al., Gastroenterology 79: 785-791, 1980. Copyright 1980 by the American GastroenteroJogical Association). 
and Willems, 1976), they postulated that a large majority of G cells originates from the replication of other gastrin cells, as the rate of increase in labelling index during the initial 1.5 days was approximately equal to the theoretical increase by mitotic replications, and estimated the turnover time as $2-4$ months. They left the origin of antral $\mathrm{G}$ cells as an unsolved matter, saying that they could not prove the origin to be either immature pregonitor cells or the neural crest. We, therefore, investigated in detail and gave a full picture of the kinetics of antral $\mathrm{G}$ cells in the hamster by flash and cumulative labelling methods which consisted of series of five and forty-one injections of ${ }^{3} \mathrm{H}$-thy midine at $6 \mathrm{hrs}$ intervals (Fujimoto et al., 1980a). We observed the labelling index of $0.3 \%$ in $\mathrm{G}$ cells by flash labelling, which confirmed the proliferative ability in some antral G cells, as LeHY and Willems (1976) previously described. The increase curve of the labelling index after five injections of ${ }^{3} \mathrm{H}$-thymidine revealed the completion of the differentiation of $\mathrm{G}$ cells within 5 days (Fig. 8). The increase of labelled $\mathrm{G}$ cells, however, was much higher than the theoretical increase by self-replication. Thus, the renewal of antral G cells was ascribed to some process other than selfproliferation. The pattern of regression of the labelling index (Fig. 9) and time course of the spatial distribution of labelled G cells (Fig. 10) after cumulative labeling for 10 days indicated that $G$ cells migrate downwards from the isthmus with time and are lost randomly ("random loss system") with a half life of 10-15 days. From these results it was concluded that a large majority of antral $\mathrm{G}$ cells originates from the immature precursor cells (generative cells) at the isthmus of pyloric glands and show downward migration, while a small number of $\mathrm{G}$ cells undergo mitosis.

$\mathrm{G}$ cells in the duodenal mucosa are distributed in both the villi and the crypts, but usually more numerous in the latter. In our recent observation, only a small number of $\mathrm{G}$ cells in the duodenal crypts of the rat were labelled, while most were non-labelled after a single injection of ${ }^{3} \mathrm{H}$-thymidine; one third of the $\mathrm{G}$ cells, especially those in the villi, were labelled on the second day after five injections at $6 \mathrm{hr}$ intervals. This indicated that most $\mathrm{G}$ cells in the rat duodenum were produced from the immature precursor cells in the crypts and their functional differentiation was completed within 3 days. Almost all were replaced by non-labelled cells within 3-4 days, which indicated

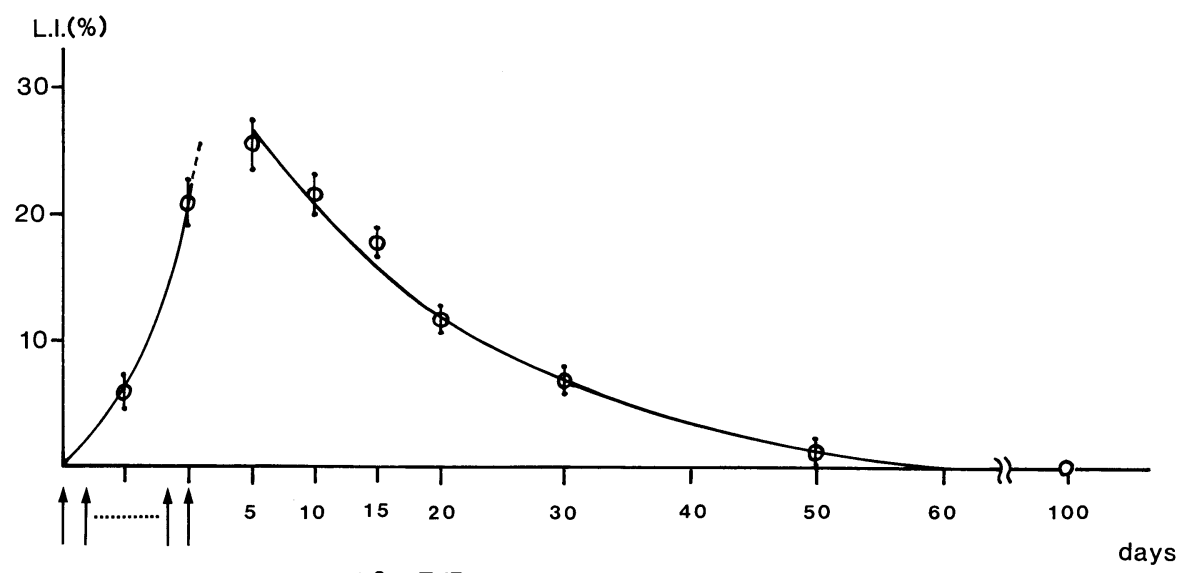

41 repeated injections of $3 \mathrm{H}-\mathrm{TdR}$

Fig. 9. Labelling index of $\mathrm{G}$ cells during and after a series of 41 injections of ${ }^{3} \mathrm{H}$-thymidine. (Reprinted by permission of the publisher from the article by S. Fujimoto et al., Gastroenterology 79: 785-791, 1980. Copyright 1980 by the American Gastroenterological Association). 


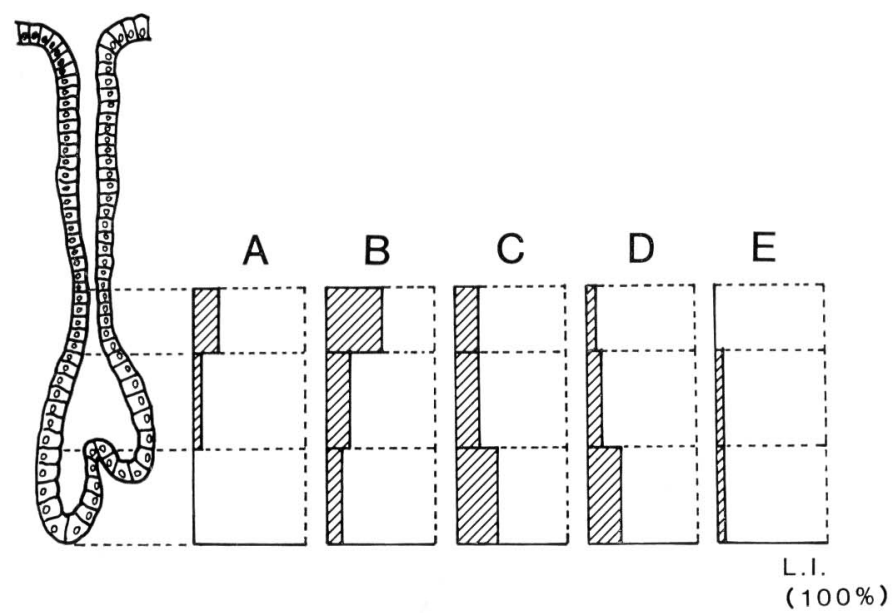

Fig. 10. Spatial distribution of labelled G cells on various days. (Reprinted by permission of the publisher from the article by S. Fujiмото et al., Gastroenterology 79: 785-791, 1980. Copyright 1980 by the American Gastroenterological Association). A: 5th day of cumulative labelling. B: 10th day of cumulative labelling. C: 10th day of pulse labelling. D: 20th day of pulse labelling. E: 50th day of pulse labelling.

that the $G$ cells after maturation migrated upwards and were lost within 3-4 days. From this preliminary study we inferred the renewal pattern of $G$ cells in the duodenum as shown in Figure 11.

Thus, $\mathrm{G}$ cells in two different sites, i.e., pyloric and duodenal mucosa, show different kinetic behaviors. The kinetics of antral G cells is quite similar to that of antral EC cells, while the kinetics of duodenal G cells is similar to that of EC cells in the small intestine. The cellular kinetics of them, consequently, depends on where they are rather than what they are.

\section{The S cell}

In recent years we have also studied the kinetics of secretin cells (S cells) in rat duodenum. According to all existing reports, opinion is divided over the spatial distribution of $\mathrm{S}$ cells in the duodenum. Some investigators reported that $\mathrm{S}$ cells were more numerous in the crypts (Bussolati et al., 1971) or at the transitional zone (Polak et al., 1971a, b; Chey and Escoffery, 1976), while others found them mainly in the villi (LARSSON et al., 1977). In our observation of the rat, S cells were distributed from the transitional zone to the villus tip and more numerously in the upper two thirds of the villi. This result agrees with the observation of KRAwitT et al. (1966) who reported that the bioactivity of secretin was concentrated in the transitional zone and villi.

In our preliminary study by ${ }^{3} \mathrm{H}$-thymidine autoradiography, the $\mathrm{S}$ cell showed no proliferative ability, and over $60 \%$ of the S cells in the villi were labelled on the second day after five injections of ${ }^{3} \mathrm{H}$-thymidine at $6 \mathrm{hr}$ intervals. All labelled cells were then replaced by non-labelled cells within 2 days. From these results, we calculated the renewal pattern of $\mathrm{S}$ cells as shown in Figure 12. It is thought that the reason why no $\mathrm{S}$ cell was found in the crypt of the duodenum is because its functional differentiation does not occur till the cell reaches the villi.

\section{Other endocrine cells in the gut mucosa}

Although more than fifteen kinds of gut endocrine cells have been identified, we have 


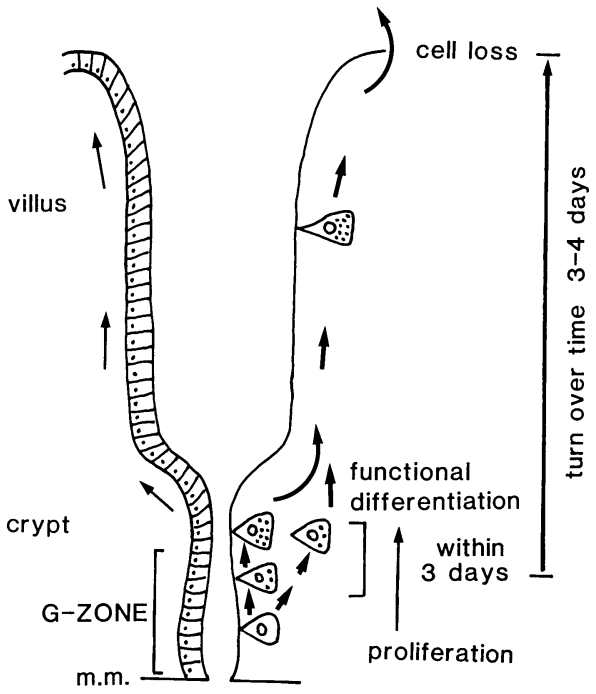

Fig. 11. Diagram of $G$ cell kinetics in the rat duodenum. The functional differentiation of $\mathrm{G}$ cells is completed in a crypt within 3 days after the proliferation from immature precursor cells. After the maturation, the cells migrate towards the villus tip and are lost with life span of 3-4 days.

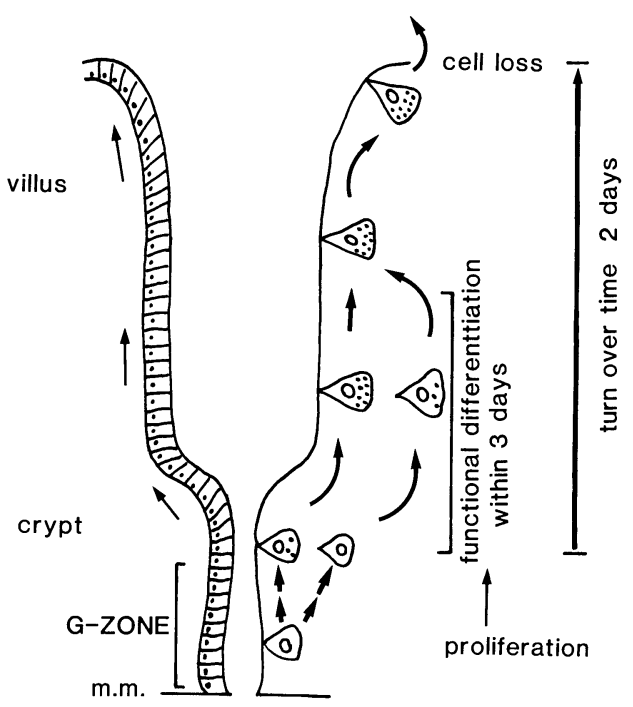

Fig. 12. Diagram of $\mathrm{S}$ cell kinetics in the rat duodenum. The maturation of $\mathrm{S}$ cells occurs during the migration along a villus within 3 days. The mature $\mathrm{S}$ cells are lost with life span of 2 days.

very little knowledge about the kinetics of those cells except for EC, G and S cells, thus far. As far as the small intestine is concerned, however, almost all cells throughout the crypts and villi can be labelled by consecutive administrations of ${ }^{3} \mathrm{H}$-thymidine, and there is no definite cell free from the labelling. It seems reasonable to conclude that all mucosal cells of the small intestine are derived from the generative cells in crypts and renewed continuously.

\section{FACTORS INFLUENCING THE CELLULAR DYNAMICS OF GUT ENDOCRINE CELLS}

At present we must admit that the factors which might influence the cellular dynamics of gut endocrine cells mostly remain unknown subjects. So far, hyperplasia of antral gastrin cells with chronic antral stimulation (LEHY et al., 1975) and in several pathological states (CReutzfeld et al., 1971; Polak et al., 1971c, d; Pearse et al., 1972) have been described, so it seems that some intrinsic or extrinsic factors could influence the kinetics of gut endocrine cells, such as the antral G cells.

Although we now understand that the $\mathrm{G}$ cell population is continuously renewed, it is not known what is responsible for the hyperplastic state among different possible mechanisms such as an increased renewal rate, a shortening of differentiation time or a prolonged life span of antral G cells, or their combination. In this chapter our observations, which might give some clues to those questions, are discussed. 


\section{The $\mathbf{G}$ cell population in histopathological alterations}

StockbrugGer et al. (1977) described histopathological alterations such as a reduced G cell population in human antral gastritis. Lately, we confirmed their observation and, in addition, found no $\mathrm{G}$ cells in the area occupied by intestinal metaplasia (Fujımoto et al., 1980b).

Antral gastritis is characterized by inflammatory cell infiltration and a decrease in glandular cells. Therefore, the reduced G cell population is thought to be a decrease proportional with the other components. By contrast, the finding that no $G$ cell exists in the intestinalized glands indicates that an intestinalized gland is incapable of producing $\mathrm{G}$ cells.

RUBin (1969), on the other hand, described the proliferation of endocrine cells in atrophic fundic mucosa in patients with pernicious anemia characterized by the disappearance of normal fundic glands and replacement with pseudopyloric glands or intestinal metaplasia. Lately, Creutzfeld et al. (1971) and PolaK et al. (1971c, 1973) found $G$ cells in the fundic gland area in patients with pernicious anemia. As basically no $G$ cell exists in the fundic gland area, the origin of these G cells is apparently mysterious.

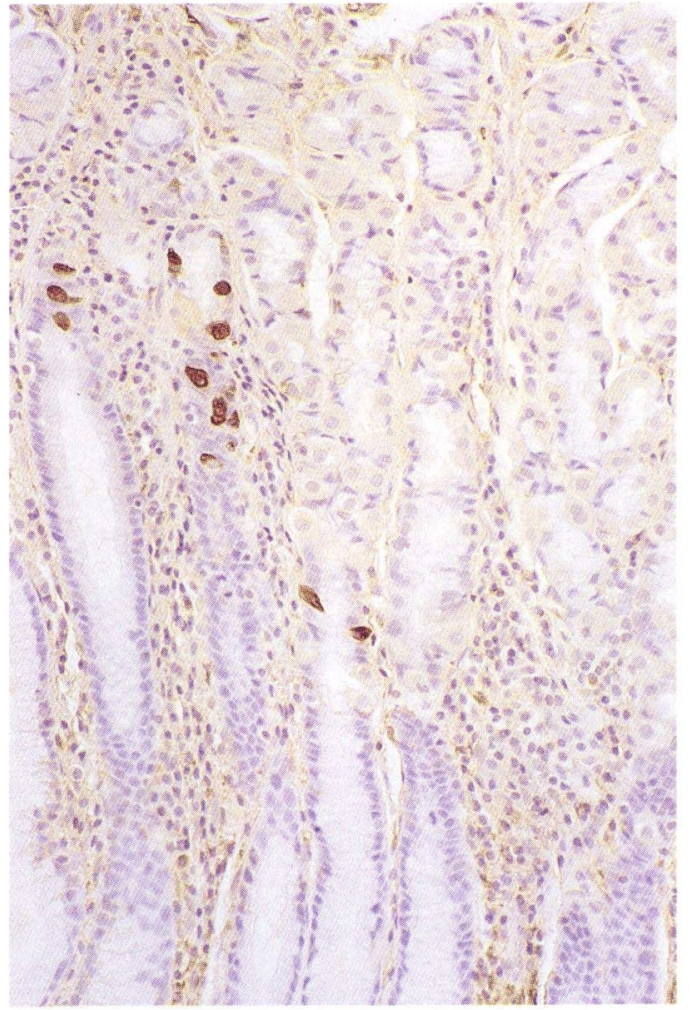

Fig. 13. Transformation of the fundic gland into the pseudopyloric gland containing $\mathrm{G}$ cells along the fundo-pyloric border in human gastric mucosa. A pseudopyloric change starts at the neck portion of the fundic gland, then progresses downwards.
Recently we found G cells in the regenerated pseudopyloric glands after mucosal injury, and observed the transformation of a normal fundic gland into a pseudopyloric gland containing $\mathrm{G}$ cells along the fundo-pyloric border (Fig. 13) in a resected human stomach. It is certain that this alteration in glandular architecture comes from the characteristic change in immature precursor cells at the generative cell zone, i.e., precursor cells producing fundic gland components such as chief cells and parietal cells which seem to have been transformed to those producing other cell types such as mucoid cells and $G$ cells. This seems to be a possible explanation for the origin of $G$ cells in the fundic gland area, because a pseudopyloric change appears to be inevitable in atrophic gastritis in patients with pernicious anemia.

\section{G cell hyperplasia after vagotomy}

In man and the rat, hypergastrinemia (Becker et al., $1973 \mathrm{a}, \mathrm{b}$; SchrumpF et al., 1974; Delince et al., 1978; HÅkanson et al., 1974; Alumets et al., 1980), increase in antral gastrin content (Becker et al., 1973b; Hughes 
and Hernandez, 1976) and G cell hyperplasia (Delince et al., 1978; Alumets et al., 1980) have been described after vagotomy. These observations were obtained at least 3 weeks after vagotomy. In ${ }^{3} \mathrm{H}$-thymidine autoradiography of the antral portion of hamsters by the flash labelling method during the 7 days after vagotomy, we observed a remarkable expansion of the generative cell zone in the pyloric glands at $24 \mathrm{hrs}$ after vagotomy (Fig. 14), and also an increased labelling index of $\mathrm{G}$ cells as high as 7-8 times that of the controls. The labelling index increased more or less transiently and gradually diminished, settling at slightly high values compared to the controls (unpublished data).

These findings indicate that not only $\mathrm{G}$ cells but other mucosal cells in the pyloric glands were affected and responded to the denervation at such early stages as $24 \mathrm{hrs}$

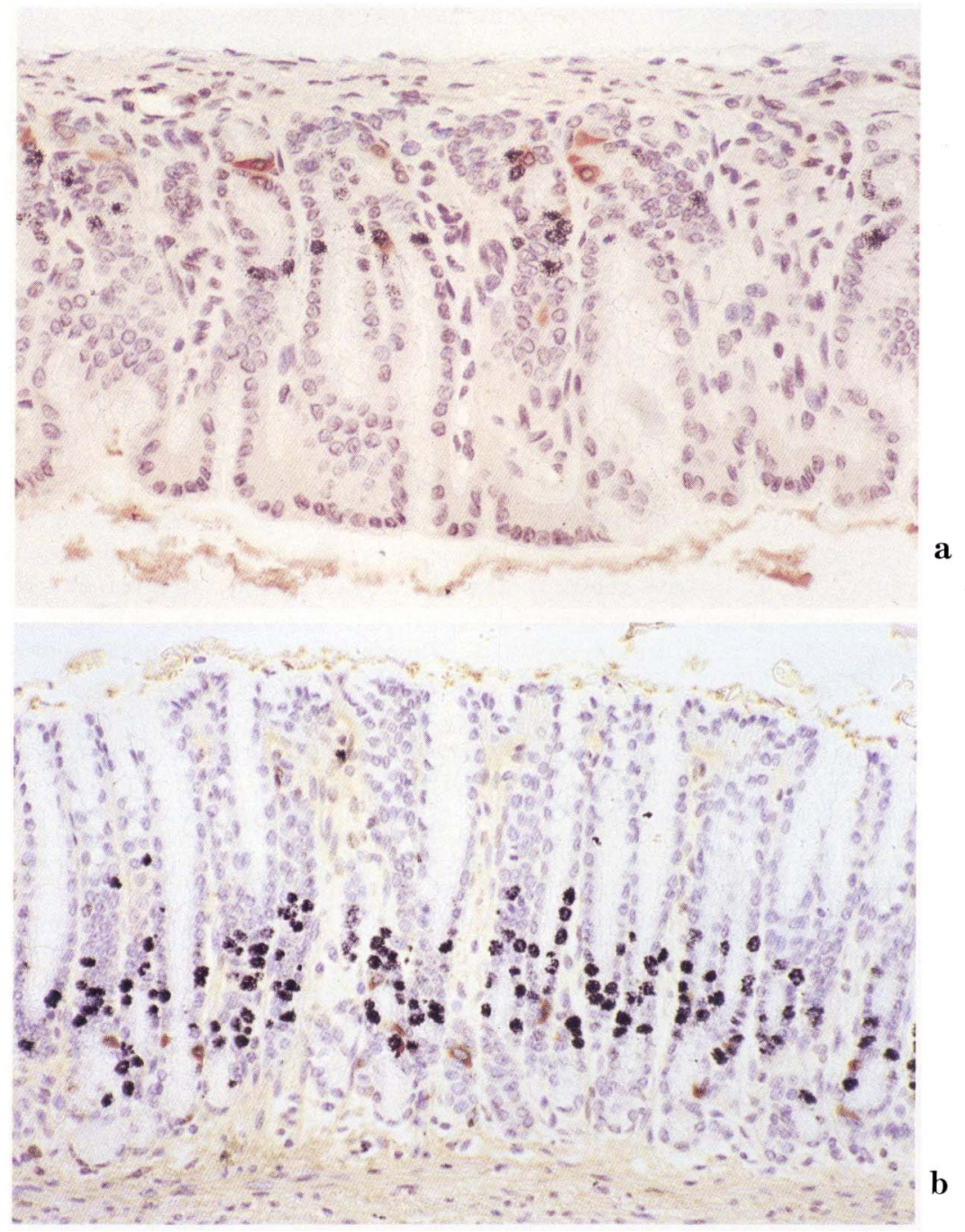

Fig. 14. Autoradiograph of the pyloric mucosa of the hamster. a. Control, b. $24 \mathrm{hrs}$ after vagotomy; note the expansion of the generative cell zone. 
after vagotomy. As far as $\mathrm{G}$ cells were concerned, it was obvious that $\mathrm{G}$ cells capable of mitosis increased significantly in number during the $24 \mathrm{hrs}$ after vagotomy. However, it is unclear whether such an increase in the $\mathrm{G}$ cell population with mitotic ability is due to rapid functional differentiation of the cell prior to loss of mitotic activity, its preserved mitotic ability after maturation, or its recovered mitotic ability at its full maturity. The life span of $\mathrm{G}$ cells after vagotomy is also unknown.

Many factors other than histopathological alterations and denervation may also influence the kinetics of gut endocrine cells, for example the interaction of various kinds of hormones including gut hormones, or the administration of drugs, etc. These issues thus far remain unsolved.

In summary, gut endocrine cells come from the same origin as other cell types of endoderm and never represent a special cell group in mucosal cell dynamics. A generative cell in each part of the gut mucosa is multipotential in its differentiation and maintains the site-specific mucosal architecture of the gastrointestinal tract. However, many questions, i.e., what sort of stimuli might determine their differentiation into endocrine cells under normal or pathological conditions, how the alteration of this cellular kinetics might be induced by the stimuli and whether or not it might involve other types of cells, remain to be solved in future studies.

\section{REFERENCES}

Alumets, J., H. A. El Munshid, R. Håkanson, J. Hedenbro, G. Liedberg, J. Oscarson, J. F. Rehfeld, F. Sundler and S. Vallgren: Gastrin cell proliferation after chronic stimulation: Effect of vagal denervation or gastric surgery in the rat. J. Physiol. 298: 557-569 (1980).

Andrew, A., B. Kramer and B. B. Rawdon: The embryonic origin of endocrine cells of the gastrointestinal tract. Gen. comp. Endocrinol. 47: 249-265 (1982).

Becker, H. D., D. D. Reeder and J. C. Thompson: Effect of truncal vagotomy with pyloroplasty or with anterectomy on food-stimulated gastrin values in patients with duodenal ulcer. Surgery 74: 580-586 (1973a).

: Influence of vagotomy on tissue gastrin levels in stomach and pancreas in rats. Surgery $74: 778-782(1973 \mathrm{~b})$.

Bertalanffy, F. D. and K. P. Nagy : Mitotic activity and renewal rate of the epitherial cells of human duodenum. Acta anat. 45: 362-370 (1961).

Bizzozero, G.: Über die Regeneration der Elemente der schlauchförmigen Drüsen und des Epithels des Magendarmkanals. Anat. Anz. 3: 781-784 (1888).

-: Über die schlauchförmigen Drüsen des Magendarmkanals und die Beziehungen ihres Epithels zu dem Oberflächenepithel der Schleimhaut. Arch. mikrosk. Anat. 42: 82-152 (1893).

Bussolati, G., C. Capella, E. Solcia, G. Vassallo and P. Vezzadini : Ultrastructural and immunofluorescent investigations on the secretin cell in the dog intestinal mucosa. Histochemie 26: 218-227 (1971).

Cairnie, A. B.: Renewal of goblet and Paneth cells in the small intestine. Cell Tiss. Kinet. 3: 35-45 (1970).

Cairnie, A. B., L. F. Lamerton and G. G. Steel : Cell proliferation studies in the intestinal epithelium of the rat. I. Determination of the kinetic parameters. Exp. Cell Res. 39: 528-538 (1965).

Chang, W. W. L. and C. P. Leblond: Renewal of the epithelium in the descending colon of the mouse. I. Presence of three cell populations: vacuolations: vacuolated-columnar, mucous and argentaffin. Amer. J. Anat. 131: 73-120 (1971). 
Chang, W. W. L. and N. J. Nadler: Renewal of the epithelium in the descending colon of the mouse. IV. Cell population kinetics of vacuolated-columnar and mucous cells. Amer. J. Anat. 144: 39-56 (1975).

Cheng, H.: Origin and differentiation and renewal of the four main epithelial cell types in the mouse small intestine. 2. Mucous cells. Amer. J. Anat. 141: 481-502 (1974a).

- : Origin and differentiation and renewal of the four main epithelial cell types in the mouse small intestine. 4. Paneth cells. Amer. J. Anat. 141: 521-536 (1974b).

Cheng, H. and C. P. Leblond: Origin and differentiation and renewal of the four main epithelial cell types in the mouse small intestine. 1. Columnar cell. Amer. J. Anat. 141: 461-480 (1974a). : Origin and differentiation and renewal of the four main epithelial cell types in the mouse small intestine. 3. Entero-endocrine cells. Amer. J. Anat. 141: 503-520 (1974b).

_-_ : Origin and differentiation and renewal of the four main epithelial cell types in the mouse small intestine. 4. Unitarian theory of the origin of the four epithelial cell types. Amer. J. Anat. 141: 537-562 (1974c).

Cheng, H., J. Merzel and C. P. Leblond: Renewal of Paneth cells in the small intestine of the mouse. Amer. J. Anat. 126: 507-526 (1969).

Chey, W. and R. Escoffery : Secretin cells in the gastrointestinal tract. Endocrinology 98: 13901395 (1976).

Creutzfeldt, W., R. Arnord, C. Creutzfeldt, G. Feurle and H. Ketterer: Gastrin and G-cells in the antral mucosa of patients with pernicious anemia, acromegaly and hyperparathyroidisms and in a Zollinger-Ellison tumor of the pancreas. Europ. J. clin. Invest. 1: 461-479 (1971).

Delince, P., G. Willems and J. De Graef : Antral gastrin cell proliferation after vagotomy in rats. Digestion 18: 27-34 (1978).

Deschner, E. E. and M. Lipkin : An autoradiographic study of the renewal of argentaffin cells in human rectal mucosa. Exp. Cell Res. 43: 661-665 (1966).

Ferreira, M. N. and C. P. Leblond: Argentaffin and other "endocrine" cells of the small intestine in the adult mouse. 2. Renewal. Amer. J. Anat. 131: 331-352 (1971).

Fujimoto, S., T. Hattori, K. Kimoto, S. Yamashita, S. Fujita and K. Kawai : Tritiated thymidine autoradiographic study on origin and renewal of gastrin cells in antral area of hamsters. Gastroenterology 79: 785-791 (1980a).

Fujimoto, S., K. Kimoto, H. Inokuchi, K. Kawai, S. Yamashita and T. Hattori : G-cell population and serum gastrin response to cimetidine-OXO test meal in relation to histopathological alterations in resected stomachs from patients with pertic ulcer disease. Gastroent. Jap. 15: 101-107 (1980b).

Hagemann, R. E., C. R. Sigdestad and S. Lesher : A quantitative description of the intestinal epithelium of the mouse. Amer. J. Anat. 129: 41-52 (1970).

Håkanson, R., J. H. Kroesen, G. Liedberg, J. Oscarson, J. F. Rehfeld and F. Stadil : Correlation between serum gastrin concentration and rat stomach histidine decarboxylase activity. J. Physiol. 243: 483-498 (1974).

Hattori, T.: On cell proliferation and differentiation of the fundic mucosa of the golden hamster. Fractographic study combined with microscopy and ${ }^{3} \mathrm{H}$-thymidine autoradigraphy. Cell Tiss. Res. 148: 213-226 (1974). : : The morphology of the stomach. In: (ed. by) K. Kawai: The stomach. Its morphology and function. (In Japanese). Igaku-Shoin, Tokyo. 1975 (p. 6-45).

Hattori, T. and S. Fujita: Tritiated thymidine autoradiographic study on cellular migration in the gastric gland of the golden hamster. Cell Tiss. Res. 172: 171-184 (1976a).

: Tritiated thymidine autoradiographic study of cell migration and renewal in the pyloric mucosa of golden hamsters. Cell Tiss. Res. 175: 49-57 (1976b).

Hattori, T., H. Niki and S. Fujita: Tritiated thymidine autoradiographic study on the origin and renewal of argentaffin cells in the pyloric gland of hamsters. Cell Tiss. Res. 181: 15-25 (1977).

Heidenhain, R.: Untersuchungen über den Bau der Labdrüsen. Arch. mikrosk. Anat. 6: 368-406 (1870).

Hughes, W. S. and A. J. Hernandez : Antral gastrin concentration in patients with vagotomy and 
pyloroplasty. Gastroenterology 71: 720-722 (1976).

Hunt, T. E. and E. A. Hunt: Radioautographic study of proliferation in the stomach of rat using thymidine- ${ }^{3} \mathrm{H}$ and compound 48/80. Anat. Rec. 142: 505-517 (1962).

Inokuchi, H., K. Kawai, Y. Takeuchi and Y. Sano: Immunohistochemical demonstration of EC cells in rat gastrointestinal tract. Histochemistry 74: 453-456 (1982).

Kaku, H.: Dynamic analysis of the stomach epithelium. ${ }^{3} \mathrm{H}$-thymidine autographic study. (Japanese text with English abstract). Arch. histol. jap. 27: 223-246 (1966).

Kaku, H., A. Kojima, K. Hayashi, M. Horii, K. Naka mura and S. Fujita : Analytical studies on the cytodynamics of the intestinal epithelium. (Japanese text with English abstract). Arch. histol. jap. 23: 7-19 (1962).

Kovacs, L. and C. S. Potten: An estimation of proliferative population size in stomach, jejunum and colon of DBA-Z mice. Cell Tiss. Kinet. 6: 125-134 (1973).

Krawitt, E. L., G. R. Zimmerman and J. A. Clifton : Location of secretin in dog duodenal mucosa. Amer. J. Physiol. 211: 935-938 (1966).

Kultschitzky, N.: Zur Frage über den Bau des Darmkanals. Arch. mikrosk. Anat. 49: 7-35 (1897).

Larsson, L.-I., F. Sundler, J. Alumets, R. Håkanson, O. B. Schaffalitzky de Muckadell and J. Fahrenkrug: Distribution, ontogeny and ultrastructure of the mammalian secretin cell. Cell Tiss. Res. 181: 361-368 (1977).

Leblond, C. P. and B. Messier: Renewal of chief cells and goblet cells in the small intestine as shown by radioautography after injection of thymidine- ${ }^{3} \mathrm{H}$ into mice. Anat. Rec. 132: 247-259 (1958).

Leblond, C. P. and C. E. Stevens: The constant renewal of the intestinal epithelium in the albino rat. Anat. Rec. 100: 357-377 (1948).

Lehy, T., N. Voillemot, M. Dubrasquet and F. Dufougeray : Gastrin cell hyperplasia in rats with chronic antral stimulation. Gastroenterology 68: 71-82 (1975).

Lehy, T. and G. Willems : Combined use of immunocytochemical and autoradiographic techniques for studying the renewal of gastrin cells. Biomed. Express 23: 443-446 (1975). 614-619 (1976).

Lipkin, M., P. Sherlock and B. Bell: Cell preliferation kinetics in the gastrointestinal tract of man. II. Cell renewal in stomach, ileum, colon and rectum. Gastroenterology 45: 721-729 (1963).

McGuigan, J. E.: Gastric mucosal intracellular localization of gastrin by immunofluorescence. Gastroenterology 55: 315-327 (1968).

Merzel, J. and C. P. Leblond: Origin and renewal of goblet cells in the epithelium of the mouse small intestine. Amer. J. Anat. 124: 281-306 (1969).

Messier, B. and C. P. Leblond : Cell proliferation and migration as revealed by radioautography after injection of thymidine- ${ }^{3} \mathrm{H}$ into male rats and mice. Amer. J. Anat. 106: 247-285 (1960).

Niki, H.: Studies on architectures and cellular kinetics of duodenal mucosa. J. Kyoto. Pref. Univ. Med. 89: 717-734 (1980).

Odartchenko, N., C. Hedinger, J. Ruzicka and E. Weber: Cytokinetics of argentaffin cells in mouse intestinal mucosa. Virchows Arch. Abt. B Zellpathol. 6: 132-136 (1970).

Patzelt, V.: Der Darm. In: Möllendorffs Handbuch der mikroskopischen Anatomie des Menschen. V/3. Springer-Verlag, Berlin, 1936 (p. 111-120).

Pearse, A. G. E. : Common cytochemical properties of cells producing polypeptide hormones, with particular reference to calcitonin and the thyroid C cells. Vet. Rec. 79: 587-590 (1966).

-: Common cytochemical and ultrastructural characteristics of cells producing polypeptide hormones (the APUD series) and their relevance to thyroid and ultimobranchial $\mathrm{C}$ cells and calcitonin. Proc. Roy. Soc. B. 170: 71-80 (1968).

-: The cytochemistry and ultrastructure of polypeptide hormone-producing cells of the APUD series and the embriologic, physiologic and pathologic implication of the concept. J. Histochem. Cytochem. 17: 303-313 (1969).

: The diffuse neuroendocrine system and the APUD concept: Related 《endocrine》peptides in brain, intestine, pituitary, placenta, and anuran cutaneous gland. Med. Biol. 55: 115-125 (1977). 
Pearse, A. G. E. and J. M. Polak: Neural crest origin of the endocrine polypeptide (APUD) cells of the gastro-intestinal tract and pancreas. Gut 12: 783-788 (1971).

Pearse, A. G. E., G. Bussolati and J. M. Polak : Immunofluorescent studies on the G cells in normal and abnormal gastric mucosa. Acta. hepato-gastroenterol. 19: 291-295 (1972).

Polak, J. M., S. Bloom, I. Coulling and A. G. E. Pearse: Immunofluorescent localization of secretin in the canine duodenum. Gut $12.605-610$ (1971a). glucagon in human intestinal mucosa. Scand. J. Gastroenterol. 6: 739-744 (1971b).

Polak, J. M., I. Coulling and W. Doe: The G cells in pernicious anaemia. Gut 12: 319-323 (1971c).

Polak, J. M., G. Bussolati and A. G. E. Pearse: Cytochemical immunofluorescence and ultrastructural investigation of the G cells in hyperparathyroidism. Virchows Arch. (Zellpathol.) 9: 187197 (1971d).

Polak, J. M., A. V. Hoffbrand, P. I. Reed, S. Bloom and A. G. E. Pearse: Qualitative and quantitative studies of antral and fundic G cells in pernicious anaemia. Scand. J. Gastroenterol. 8: 361-367 (1973).

Quastler, H. and F. G. Sherman : Cell population kinetics in the intestinal epithelium of the mouse. Exp. Cell Res. 17: 420-438 (1959).

Rubin, W.: Proliferation of endocrine-like (enterochromaffin) cells in atrophic gastric mucosa. Gastroenterology 57: 641-648 (1969).

Schrumpf, E., M. Roland and I. Liavåg: Serum gastrin and gastric acid secretion before and after proximal gastric vagotomy. Scand. J. Gastroenterol. 9: 115-118 (1974).

Schultze, B., V. Haack, A. C. Schmeer and W. Maurer: Autoradiographic investigation on the cell kinetics of crypt epithelium in the jejunum of the mouse. Cell Tiss. Kinet. 5: 131-145 (1972).

Shimamoto, K.: Autoradiographic studies on mucin metabolism of gastrointestinal epithelium. J. Kyoto Pref. Univ. Med. 79: 1-20 (1970).

Stockbrugger, R., L. I. Larsson, G. Lundqvist and L. Angervall : Antral gastrin cells and serum gastrin in achlorhydria. Scand. J. Gastroenterol. 12: 209-213 (1977).

Sunter, J. P., A. J. Watson, N. A. Wright and D. R. Appleton: Cell proliferation at different sites along the length of the rat colon. Virchows Arch. B Cell Pathol. 32: 75-87 (1979).

Troughton, W. D. and J. S. Trier: Paneth and goblet cell renewal in mouse duodenal crypts. J. Cell Biol. 41: 251-268 (1969).

Tsubouchi, S. and C. P. Leblond : Migration and turn over of entero-endocrine and caveolated cells in the epithelium of the descending colon, as shown by radioautography after continuous infusion of ${ }^{3} \mathrm{H}$-thymidine into mice. Amer. J. Anat. 156: 431-452 (1979).

Willems, G., P. Galand, Y, Vansteenkiste and P. Zeitoun: Cell population kinetics of zymogen and parietal cells in the stomach of mice. Z. Zellforsch. 134: 505-518 (1972).

\author{
川井啓市 \\ 干602 京都市上京区河原町広小路 \\ 京都府立医科大学 \\ 公衆衛生学教室
}

Prof. Keiichi Kaw AI

Department of Preventive Medicine

Kyoto Prefectural University of Medicine

Kawaramachi-Hirokoji

Kyoto, 602 Japan 